\title{
Translating business cultures: anglicisms in German discourse
}

\author{
Elena Rudenko $^{1, *}$, Nargilya Gadzhieva ${ }^{2}$, and Ira Agasieva ${ }^{3}$ \\ ${ }^{1}$ Don State Technical University, 344000, Rostov-on-Don, Russia \\ ${ }^{2}$ Dagestan State University of National Economy, 367008, Makhachkala, Russia \\ ${ }^{3}$ Dagestan State Technical University, 367015, Makhachkala, Russia
}

\begin{abstract}
The paper explores assimilation strategies employed to integrate anglicisms into German written business discourse. The study was carried out on the textual level, which gives valuable insight into the rules and norms governing business communication and thus contributes to a better understanding of written conventions deemed appropriate within business discourse communities. The authors hold the view that assimilation problem can be treated as translation problem. In accordance with this view anglicisms were evaluated in respect to the strategies of foreignisation and neutralization understood as different degrees of assimilation. The results show that neutralizing strategy aimed at mixing borrowed and native language units outweighs quantitatively the foreignising strategy, which indicates the overall trend towards a balanced approach to the incorporation of anglicisms. The authors conclude that assimilation strategies applied to anglicisms should be consistent with the purposes and objectives of professional communication. Thus developing adequate assimilation strategies ensures optimal transmission of ideas and improves text coherence.
\end{abstract}

\section{Introduction}

The current phase of accelerated globalization fostered by the introduction of ICT and social media entails considerable convergence between the word stocks of European languages. This convergence occurs due to continuously increasing number of anglicisms. Connotations regarding the spread of English vary considerably, "ranging from "unique", "easy-to-learn", "most influential" to "catastrophic", "eurocentric", "triumphalist", "language imperialism" and even "language fascism" [1].

A study conducted by I. Kick showed that no other European country has so many English advertising slogans as Germany does [2]. The influx of anglicisms into German is not always viewed positively, since language could become a barrier rather than a means to communication when flooded with incomprehensible words.

\footnotetext{
*Corresponding author: RudenkoElena1988@yandex.ru
} 
Many linguists and translatologists continue to pay close attention to the presently occurring penetration of English borrowings into the German language. However, taking into consideration the size of the problems related to the incorporation of foreign items into the inventory of the recipient language, efforts in this field are still insufficient. English borrowings have been investigated from a phraseological perspective [3, 4], particular attention has been paid to catachrestic and non-catachrestic borrowings [5, 6, 7]. M. Garley emphasizes the need for close attention to be given to morphological borrowing, specifically, in the domain of the German hip-hop community [8], whereas A. Zhiganova focuses on native speakers' perception of English-sourced elements in German advertising [9].

While the aforementioned studies have mainly focused on large-scale language corpora (transcribed radio corpus, word corpus of German hip-hop discussion), few studies have investigated anglicisms within continuous text. This approach permits a more thorough understanding of assimilation strategies applied to anglicisms within a single coherent structure and thus provides a holistic perspective.

The purpose of this research is to consider assimilation strategies applied to anglicisms with particular emphasis on anglicisms embedded in German written business discourse.

The study is divided into a number of sub-aims:

- to classify anglicisms in line with the assimilation strategy applied within the written business discourse;

- to identify the prevailing assimilation strategy;

- to suggest practical solutions to ensure adequate incorporation of anglicisms.

We consider necessary to define the term "anglicism" used in the following analysis. When viewed diachronically, anglicisms originate from an English background, when viewed from a synchronic perspective, they reflect some features of the English language. The assignment to the category "anglicism" in this study wasn't based exclusively on diachronically motivated decisions (on dictionaries). The primary factor behind the assignment was the availability of phonetic, graphic, semantic and morphemic features, which is why loan translations (calques) were excluded from the analysis. Therefore, we suggest the following definition of anglicisms, namely 'lexical and lexico-syntactic units that reflect a structural property of the English language within receiving language'.

\section{Materials and methods}

The material of this study has been obtained from the handbook aimed at assisting new entrants to the profession in mastering oratory skills - „Business-Rhetorik für Berufseinsteiger" by H. Schäfer, B. Schäfer (UVK Verlag, 2017). The first stage of this study involved the manual extraction of anglicisms from the source text.

After this step was completed, anglicisms were analysed and classified according to assimilation strategies used to integrate them into written business discourse. We hold the view that assimilation problem can be treated as translation problem, therefore we have divided anglicisms into two groups according to the strategy applied. The textual material on which the present research is based was carefully scrutinized at different levels of the language system (graphic, phonemic, morphemic, syntactic, semantic, textual) to determine assimilation strategies used to integrate anglicisms into the host language. In translation studies translations are evaluated in respect to the foreignising and domesticating strategy, in this paper anglicisms were evaluated in accordance with different degrees of assimilation: foreignising strategy is represented by anglicisms retaining their foreign appearance or showing signs of a relatively loose integration, neutralizing strategy - neutral position between foreignising and domesticating strategy - is represented by juxtaposition of borrowed and native elements. As mentioned above, loan translations were excluded from this analysis, and that is why domesticating strategy is not present. To analyse and classify 
manually extracted anglicisms, a descriptive method, text and contextual-analysis methods have been applied.

\section{Results}

Anglicisms that exhibit different degrees of assimilation were distributed as follows:

1) code-mixing

2) partially integrated borrowings

3) double nomination

4) hybrids
a) hybrid compound nouns
b) adjectival compounds
c) phrasal compounds

The foreignising strategy is represented by code-mixing and partially integrated lexical borrowings since their overall morphemic shape is recognisably English, and they do not show intrinsic fusion with German elements. Double nomination and hybrid anglicisms illustrate the neutralizing strategy since here we are confronted with a mixture of borrowed and native elements.

Classification of anglicisms according to identified assimilation strategies is given below.

Table 1. Code-mixing (foreignising strategy).

\begin{tabular}{|l|l|}
\hline $\begin{array}{c}\text { Anglicisms } \\
\text { under study }\end{array}$ & \multicolumn{1}{c|}{ Contextual usage of Anglicisms } \\
\hline one size fits all & $\begin{array}{l}\text { Aber es gibt keinen goldenen Weg zur guten Rede, nach dem Motto } \\
\text { one size fits all. }\end{array}$ \\
\hline Last but not least & $\begin{array}{l}\text { Last but not least: Vergessen Sie nicht }<\ldots>\text { die indirekte Anrede } \\
\text { „man“ zu vermeiden. }\end{array}$ \\
\hline
\end{tabular}

Table 2. Partially integrated borrowings (foreignising strategy).

\begin{tabular}{|l|l|}
\hline \multicolumn{1}{|c|}{$\begin{array}{c}\text { Anglicisms } \\
\text { under study }\end{array}$} & \multicolumn{1}{c|}{ Contextual usage of Anglicisms } \\
\hline Job & $\begin{array}{l}\text { Der Job wird Sie }<\ldots>\text { vor neue rhetorische Herausforderungen } \\
\text { stellen. }\end{array}$ \\
\hline Tipp & Zudem finden Sie $<\ldots>$ Checklisten mit vielen wertvollen Tipps. \\
\hline $\begin{array}{l}\text { Assessment- } \\
\text { Center }\end{array}$ & $\begin{array}{l}\text { Durch Assessment-Center können Sie }<\ldots>\text { entsprechende } \\
\text { Situationen auch simulieren. }\end{array}$ \\
\hline Smalltalk & $<\ldots>$ zur Lockerung etwas Smalltalk zu führen. \\
\hline Show & $\begin{array}{l}\text { Der Eröffnungsredner darf auf keinen Fall dem Hauptredner die } \\
\text { Show stehlen. }\end{array}$ \\
\hline Handout & $\begin{array}{l}\text { Eine solche deskriptive Rede bietet den Zuhörern im Vergleich } \\
\text { zum Lesen eines Handouts kaum einen Mehrwert. }\end{array}$ \\
\hline Brainstorming & $\begin{array}{l}\text { Die bekannteste und eine durchaus sinnvolle Methode ist das } \\
\text { Brainstorming. }\end{array}$ \\
\hline Corporate Identity & $\begin{array}{l}\text { Die Gestaltung der einzelnen Folien ist darin häufig im Hinblick } \\
\text { auf Farben und Schriften an die Corporate Identity (kurz: CI) des } \\
\text { Unternehmens angelehnt. }\end{array}$ \\
\hline Pin & $\begin{array}{l}<\ldots>\text { die Metaplanwand (auf der Sie zum Beispiel mit Pins } \\
\text { Moderationskarten befestigen können). }\end{array}$ \\
\hline Feedback & Verstehen Sie das Feedback als Geschenk $<\ldots>$. \\
\hline
\end{tabular}




\begin{tabular}{|l|l|}
\hline Fairness & $\begin{array}{l}\text { An die Fairness des Zwischenrufers gegenüber den anderen } \\
\text { Zuhörern appellieren. }\end{array}$ \\
\hline Good Business & $\begin{array}{l}\text { Good Business wird häufig in Verbindung gebracht mit: } \\
\text { Überzeugung durch erfolgreichen Umgang mit Einwänden. }\end{array}$ \\
\hline Benchmark & Orientieren Sie sich an Benchmarks. \\
\hline Benchmarking & $\begin{array}{l}\text { Sie identifizieren also die wichtigsten Problembereiche, die mittels } \\
\text { eines Benchmarkings verbessert werden sollen. }\end{array}$ \\
\hline Best Practice & $\begin{array}{l}\text { Sie führen also die Best Practices der Benchmarking-Partner ein } \\
<\ldots>\text {.. }\end{array}$ \\
\hline Headline & Stellen Sie eine Konsistenz zwischen Headline, Text und Bild her. \\
\hline Reason why & $\begin{array}{l}\text { Der sogenannte Reason why sollte beim Produkt bzw. der } \\
\text { Dienstleistung möglichst nicht offensichtlich sein. }\end{array}$ \\
\hline gebenchmarkt & Die zentrale Frage lautet: Was soll ,,gebenchmarkt“ werden? \\
\hline unfair & Ihr Gegenüber wird sichtbar unfair. \\
\hline
\end{tabular}

Table 3. Double nomination (neutralizing strategy).

\begin{tabular}{|c|c|}
\hline $\begin{array}{l}\text { Anglicisms under } \\
\text { study }\end{array}$ & Contextual usage of Anglicisms \\
\hline Plan B & $\begin{array}{l}\text { Gerade in Stresssituationen }<\ldots>\text { haben einen Plan B (was tun, } \\
\text { wenn ... passiert). }\end{array}$ \\
\hline Learning by Doing & $\begin{array}{l}\text { Ambiguitätstoleranz bauen Sie durch Learning by Doing auf - } \\
\text { indem Sie sich in Ihrem Alltag bewusst Widersprüchen aussetzen. }\end{array}$ \\
\hline Flow & $\begin{array}{l}<\ldots>\text { ein Fluss von Begrifflichkeiten, ein sogenannter Flow, } \\
\text { entsteht. }\end{array}$ \\
\hline Overacting & $\begin{array}{l}<\ldots>\text { ein sogenanntes Overacting, also einen übertriebenen } \\
\text { Einsatz der Körpersprache. }\end{array}$ \\
\hline Clustering & $\begin{array}{l}\text { Beim Clustering versuchen Sie Ähnlichkeitsstrukturen } \\
\text { aufzudecken. }\end{array}$ \\
\hline Folienmaster & $\begin{array}{l}\text { Viele Unternehmen bieten ihren Mitarbeitern sogenannte } \\
\text { Folienmaster in PowerPoint an. Die Gestaltung der einzelnen } \\
\text { Folien ist darin häufig im Hinblick auf Farben und Schriften an die } \\
\text { Corporate Identity (kurz: CI) des Unternehmens angelehnt. }\end{array}$ \\
\hline Flipchart & $\begin{array}{l}\text { Hierzu zählen }<\ldots>\text { der Flipchart (ein mit Filzstift beschriftbarer } \\
\text { Tafelblock). }\end{array}$ \\
\hline Plot Points & $\begin{array}{l}\text { Bei den Plot Points bauen Sie einen plötzlichen Konflikt (eine } \\
\text { neue Wendung) ein, also einen Widerspruch zu Ihrem Konzept. }\end{array}$ \\
\hline Bluff & $\begin{array}{l}<\ldots>\text { der Bluff mit Fremdwörtern. Verwenden Sie allgemein } \\
\text { bekannte Fremdwörter und fragen Sie beim Gesprächspartner } \\
\text { nach, ob er diese verstanden hat. }\end{array}$ \\
\hline Pokerface & $\begin{array}{l}\text { Eine neutrale Mimik wird }<\ldots>\text { als Pokerface bezeichnet. Damit } \\
\text { verschleiern Sie Ihre eigene Haltung. }\end{array}$ \\
\hline $\begin{array}{l}\text { low involvement, } \\
\text { high involvement }\end{array}$ & $\begin{array}{l}\text { Eher geringes Interesse und weniger Kenntnisse werden low } \\
\text { involvement genannt, unter high involvement versteht man hohes } \\
\text { Interesse und ausgeprägte Kenntnisse. }\end{array}$ \\
\hline Remindertechniken & $\begin{array}{l}\text { Durch sogenannte Frequenz- und Remindertechniken erhöhen } \\
\text { Sie die Aufmerksamkeit nachhaltig - konkret durch mehrere kurze } \\
\text { und häufigere Werbespots sowie die Kombination von } \\
\text { Fernsehwerbung und Print- bzw. Onlineanzeigen. }\end{array}$ \\
\hline
\end{tabular}




\begin{tabular}{|l|l|}
\hline $\begin{array}{l}\text { unique selling } \\
\text { proposition, } \\
\text { USP }\end{array}$ & $\begin{array}{l}\text { Damit sind wir beim Marketing-Begriff des sogenannten } \\
\text { Alleinstellungsmerkmals (engl. unique selling proposition oder } \\
\text { unique selling point oder kurz USP). }\end{array}$ \\
\hline Benchmarking & $\begin{array}{l}\text { Beim sogenannten Benchmarking vergleichen Sie die eigenen } \\
\text { Produkte, Prozesse, Dienstleistungen, Strategien, Strukturen, } \\
\text { Aktivitäten }<\ldots>\text { mit den besten (Unternehmen). }\end{array}$ \\
\hline 4Ps & $\begin{array}{l}\text { Die USP muss auf die vier Dimensionen Produkt, Preis, } \\
\text { Kommunikation, Distribution (engl. 4Ps = product, price, } \\
\text { promotion, place) }<\ldots>\text { abgestimmt sein. }\end{array}$ \\
\hline Ps, +3 Service-Ps & $\begin{array}{l}<\ldots>\text { noch drei weitere Ps hinzu, die sogenannten +3 Service-Ps: } \\
\text { Sie lauten process (Prozessmanagement), people (Personalpolitik) } \\
\text { und physical evidence (Ladengestaltung etc.). }\end{array}$ \\
\hline Branding & $\begin{array}{l}\text { Der Aufbau solcher Muster }- \text { das Branding }- \text { nimmt einige Zeit in } \\
\text { Anspruch. }\end{array}$ \\
\hline EQ & $\begin{array}{l}<\ldots>\text { müssen Sie eine sog. Emotionale Intelligenz (EQ als Pendant } \\
\text { zum IQ) aufbauen. }\end{array}$ \\
\hline Lean Management & $\begin{array}{l}<\ldots>\text { bietet sich auch der Begriff Lean Management an. Darunter } \\
\text { versteht man ein ganzes Bündel von Maßnahmen, die alle der } \\
\text { Rationalisierung eines Unternehmens dienen. }\end{array}$ \\
\hline Outsourcing & $\begin{array}{l}\text { Eine wichtige Maßnahme ist dabei die Auslagerung vieler } \\
\text { Nebentätigkeiten (das Outsourcing). }\end{array}$ \\
\hline
\end{tabular}

Table 4. Hybrids (neutralizing strategy).

\begin{tabular}{|c|c|}
\hline $\begin{array}{l}\text { Anglicisms under } \\
\text { study }\end{array}$ & Contextual usage of Anglicisms \\
\hline \multicolumn{2}{|r|}{ a) hybrid compound nouns } \\
\hline AIDA-Schema & $\begin{array}{l}<_{\ldots} \ldots>\text { müssen Sie schließlich eine Vorgliederung über das } \\
\text { sogenannte AIDA-Schema }<\ldots>\text { erstellen. }\end{array}$ \\
\hline AIDA-Modell & Sie können einen Vortrag auch nach dem AIDA-Modell gestalten. \\
\hline $\begin{array}{l}\text { Overhead-Folie, } \\
\text { PowerPoint-Folie }\end{array}$ & Hierzu zählen $<\ldots>$ Overhead- und PowerPoint-Folien. \\
\hline Overheadprojektor & Orientierung am „Dauermedium“: < ..> Overheadprojektor \\
\hline SWOT-Analyse & $<\ldots>$ die SWOT-Analyse $<\ldots>$ sind dabei hilfreiche Werkzeuge. \\
\hline $\begin{array}{l}\text { Benchmarking- } \\
\text { Projekt }\end{array}$ & $\begin{array}{l}\text { Dazu müssen Sie ein Benchmarking-Projekt initiieren, das aus } \\
\text { vier Phasen besteht. }\end{array}$ \\
\hline $\begin{array}{l}\text { Benchmarking- } \\
\text { Objekt }\end{array}$ & Phase 1: Benchmarking-Objekte auswählen. \\
\hline $\begin{array}{l}\text { Benchmarking- } \\
\text { Partner }\end{array}$ & Sie führen also die Best Practices der Benchmarking-Partner ein. \\
\hline Marketing-Begriff & $\begin{array}{l}\text { Damit sind wir beim Marketing-Begriff des sogenannten } \\
\text { Alleinstellungsmerkmals }<\ldots>\text {. }\end{array}$ \\
\hline Marketingexperte & $\begin{array}{l}\text { Marketingexperten beschränken sich meist auf nur einen } \\
\text { aussagekräftigen Reason why. }\end{array}$ \\
\hline Checkliste & $\begin{array}{l}\text { Checkliste zur USP-Formulierung. } \\
\text { Zudem finden } \mathrm{Sie}<\ldots>\text { Checklisten mit vielen wertvollen Tipps. }\end{array}$ \\
\hline Feedbackgespräch & $\begin{array}{l}<. .>\text { bietet sich auch das objektivere Konzept der } \\
\text { Feedbackgespäche an. }\end{array}$ \\
\hline USP-Formulierung & Checkliste zur USP-Formulierung. \\
\hline $\begin{array}{l}\text { USP- } \\
\text { Nutzenargumentation }\end{array}$ & $\begin{array}{l}\text { Haben Sie das Produkt }<\ldots>\text { abgegrenzt, für welche(s) Sie eine } \\
\text { USP-Nutzenargumentation erarbeiten wollen? }\end{array}$ \\
\hline
\end{tabular}




\begin{tabular}{|l|l|}
\hline $\begin{array}{l}\text { USP- } \\
\text { Nutzwertanalyse }\end{array}$ & $\begin{array}{l}<\ldots>\text { um zu einer kundenorientierten Nutzenargumentation zu } \\
\text { gelangen (USP-Nutzwertanalyse)? }\end{array}$ \\
\hline Werbespot & $<\ldots>$ durch mehrere kurze und häufigere Werbespots. \\
\hline $\begin{array}{l}\text { Printanzeigen, } \\
\text { Onlineanzeigen }\end{array}$ & $\begin{array}{l}\text { die Kombination von Fernsehwerbung und Print- bzw. } \\
\text { Onlineanzeigen. }\end{array}$ \\
\hline Killereinwände & $\begin{array}{l}\text { Lassen Sie sich auf keinen Fall von sogenannten Killereinwänden } \\
\text { Ihres Kunden, wie „,kein Interesse“ oder ,zu teuer“, abschrecken. }\end{array}$ \\
\hline \multicolumn{4}{|c|}{ b) adjectival compounds } \\
\hline me-too sicher & \multicolumn{1}{|c|}{ c) phrasal compounds } \\
\hline \multicolumn{3}{|l|}{$\begin{array}{l}\text { Gut zu wissen!- } \\
\text { Boxen }\end{array}$} & $\begin{array}{l}\text { Im Text sind übrigens einige Gut zu wissen!-Boxen } \\
\text { hervorgehoben. }\end{array}$ \\
\hline Üben Sie!-Boxen & Zudem finden Sie Üben Sie!-Boxen. \\
\hline Win-win-Aspekt & $<\ldots>$ müssen Sie einen Win-win-Aspekt in der Hinterhand haben. \\
\hline
\end{tabular}

\section{Discussion}

German has a long story of borrowing from English and is constantly widening its lexical reserve through the acquisition of English-sourced linguistic units. A brief overview of the emergence of anglicisms is given below in order to better understand the present-day status of anglicisms in the German business discourse.

\subsection{Anglicisms in a cultural-historical perspective}

The emergence of anglicisms in German can be traced back to the end of the $17^{\text {th }}$ century. One possible explanation could lie in the fact that England (its political order, philosophical ideas and poetry) aroused great interest among the German population despite lack of knowledge of English. However, it would be a mistake to think that England's preeminence in the world and its key positions in essential industries solely caused the transfer of anglicisms into German. The reasons lie deeper, namely in England's diplomatic status at the international level and in its language policy on an international scale. Since 1800 England started replacing French with English when developing and maintaining international contacts. Since 1850 the British ambassadors wrote their letters, addressed to foreign countries, only in English.

After the First World War German and French suffered a great setback, the latter was displaced from its privileged position as the only language of diplomacy by the Treaty of Versailles 1919, drawn up in the English and French languages.

Cultural and historical events have greatly accelerated the borrowing process in Germany, feelings of guilt and the lack of national and patriotic consciousness after the Second World War have resulted in higher levels of acceptance towards borrowed words and expressions. After 1945 the open conflict between the two big victorious powers met a turning point with the split of Germany into two parts. This moment marked the beginning of a new epoch of Germany's cultural history, as West Germany's population had long been exposed to the Western culture.

Due to rapid post-war development the huge and pressing need to nominate new concepts and new things (e.g. in the fields of commerce, economy, technology, politics etc.) became a matter of great concern. A very considerable number of English words were introduced into the German language in the abovementioned fields.

The growth of competitive business brought a huge explosion of international marketing activity. The exchange of information within and between internationally operating 
companies is dominated by the English language, which is used as a lingua franca of business life. However, the lingua franca English "differs from 'standard English' in many ways" and "is not a straightforward solution" [10] when it comes to internal communication in a business context.

\subsection{Anglicisms within business discourse community}

The impacts of languages on international business have been much discussed [11-14]. German has a reputation for being receptive to English influence, and the language of business is often criticized by purists. Some borrowed business-related words (Marketingmix, Benchmark etc.) have definitely become part of German and are listed in Duden.

Business communication may be defined as goal-oriented communication that occurs within large structured groups (organizations) aimed at making profit. A close examination of anglicisms in German written business discourse gives valuable insight into the rules and norms governing business communication and thus contributes to a better understanding of of conventions deemed appropriate within business discourse communities.

Before starting the analysis of assimilation strategies applied to separate words and phrases of English origin, we want to briefly dwell on discourse strategies applied to the business text as a whole unit.

The text under analysis is characterized by a lack of female-specific nouns - there is no explicit reference to women, although German shows the trend toward more gender-specific language or gender-neutral language in order to ensure linguistic equality of the sexes. In German gender-inclusive reference is often made by the use of the Binnen-I ("medial capital I") (e.g. RednerInnen), the so-called Gendersternchen ("gender star") (e.g. Redner*in) and the underscored so-called Gender-Gap (e.g. Redner_in). From a language perspective the application of a gender equality strategy to male-centric nouns is more workable in languages with grammatical gender whose morphological processes (gender marking through suffixation) are still productive than in languages with no grammatical gender; English falls into the latter category. However, in the text under scrutiny masculine forms and masculine marked words predominate in order to achieve the communication objectives. One of the fundamental goals of the business discourse is striving for the highest communicative efficiency (the accomplishment of the communication task with a minimum expenditure of input); female-specific nouns are therefore viewed as superfluous and excluded. Thus, the use of androcentric nouns in the text under study aligns with the aims of business discourse and may be viewed as assimilation strategy in terms of fitting into international business culture.

The extent to which anglicization has affected business discourse is vividly illustrated by the tables. During the course of the study, at least two assimilation strategies applied to anglicisms have been identified: foreignising and neutralizing strategies.

\subsubsection{Foreignising strategy}

When we talk about foreignising strategy applied to anglicisms, we are referring to codemixing and partially integrated borrowings, as they either retain their foreign appearance (code-mixing) or show signs of a relatively loose integration (partially integrated borrowings).

Marina Yu. Semenova listed the most frequent "patterns that occur in code-mixing", namely "insertion of material from one language into the structure of another, alternation between structures, congruent lexicalization of material from different inventories into a shared grammatical structure, equivalent constraint" [15]. The type of code-mixing identified 
in the text under study can be categorized as "insertion of material from one language into the structure of another" [15]. It is not used extensively and represents set phrases, which occur in a sentence without violating syntactic structures. At the pragmatic level these set phrases express the idea of being integrated into the international business community and thus sharing the same principles and values. Besides, code-mixing represents changes in emphasis and helps to sharpen the reader's perception of the text.

Partial assimilation exhibited in the text consists in graphophonemic and morphemic features. The most distinct sign of orthographic assimilation is capitalization of English nouns, which complies with the orthographical conventions peculiar to German. However, the text contains some orthographical inconsistencies: the anglicisms "Best Practices" and "Corporate Identity" are written in uppercase letters, although it contradicts the principles of German orthography. One possible reason behind this capitalization is that these anglicisms are imported as the whole notion. At the same time there is "Reason why", showing full compliance with German orthography. Criteria of morphological assimilation include case marking and plural formation of nominal anglicisms and verbal inflection, which appears in the text only once (verb past participle - gebenchmarkt). Technically, instances of morphological assimilation can be regarded as hybrid anglicisms, as they are formed out of borrowed and native morphemes (eines Handouts, eines Benchmarkings). However, hybrid forms are related to the formation of compounds by joining two or more free morphemes (native and borrowed ones) and to affixation of borrowed bases, hence morphological assimilation is viewed in this study as partially integrated borrowing. Apart from the ending -s of the genitive singular occurring twice in the text English nouns do not exhibit German singular case endings, and the most distinct signs of morphological assimilation are definite and indefinite articles. There is only one adjective listed in the Table 2, namely "unfair". The German prefix un- corresponds to the homographic morpheme in English, and pronunciation is the only characteristic that indicates morphological independence.

Thus, the vast majority of borrowings under study undergo minimal graphophonemic and morphemic assimilation and preserve the foreignness, thus exhibiting the use of foreignising assimilation strategy.

\subsubsection{Neutralizing strategy}

Neutralizing strategy is represented in the text by double nomination and hybrid compounds. Being viewed quantitatively, this strategy is a leading assimilation strategy in the text.

The first point to consider is what is meant by the reference to a "double nomination". In the case of double nomination the word remains in the text in its original orthographic form and is juxtaposed with descriptive translations or straightforward equivalents in German. The adjective "sogenannt" is often inserted before the borrowed words, thus implying doubt as to propriety of so designating phenomena (e.g. ein sogenannter Flow, ein sogenanntes Overacting); it gives clear linguistic signal that borrowed words are not commonly used and require further explanation to ensure adequate comprehension of the text. It appears reasonable to utilize this strategy when first incorporating borrowed material into the text: borrowed words are accompanied by a descriptive translation given in brackets upon the first time of being used, further in the text the words are used in their original orthographic forms:

- haben einen Plan B (was tun, wenn ... passiert)

- der Flipchart (ein mit Filzstift beschriftbarer Tafelblock)

Double nomination enables the reader to take in the full meaning of the word, and it is an undoubted advantage of this strategy. However, it might make a text look wordy, thus adding a footnote seems to be a better option.

Sometimes instead of using brackets a separate explanation of the word is given within an independent sentence: 
- $\quad<\ldots>$ bietet sich auch der Begriff Lean Management an. Darunter versteht man ein ganzes Bündel von Maßnahmen, die alle der Rationalisierung eines Unternehmens dienen.

This strategy is not applied consistently and some irregularities occur, breaking down the coherence of text. For instance, the collocations "low/high involvement" occur in the text twice and are explained differently on different occasions, which might mislead the reader:

- Eher geringes Interesse und weniger Kenntnisse werden low involvement genannt, unter high involvement versteht man hohes Interesse und ausgeprägte Kenntnisse.

- Der Grad dieser Auseinandersetzung lässt sich jeweils in high Involvement (hohes Risiko; z.B. Kauf einer Eigentumswohnung) und low Involvement (geringes Risiko; z.B. Kauf eines Kaugummis) unterteilen.

In some instances, a German term is first introduced in the text, followed by its English equivalent, which is used hereinafter as it may often be shorter and more precise:

- Damit sind wir beim Marketing-Begriff des sogenannten Alleinstellungsmerkmals (engl. unique selling proposition oder unique selling point oder kurz USP).

Creating hybrid compounds constitutes another way of transmitting concepts from a source language. Hybrid compounding is a highly productive process in German and in some cases it can be viewed as partial translation: some hybrid compounds listed in Table 4 follow an English model and consist of a well-established anglicism and a German base: Powerpoint slides - Powerpoint-Folien, SWOT analysis - SWOT-Analyse, print ads - Printanzeigen. Other hyphenated compounds display language's potential for creative use and exhibit productive word-formation patterns with anglicisms: USP-Formulierung, USPNutzenargumentation, USP-Nutzwertanalyse; Benchmarking-Projekt, BenchmarkingObjekt, Benchmarking-Partner. We consider that creating hybrid compounds is an appropriate assimilation strategy provided that the English determinant is correctly explained or defined in the text beforehand.

\section{Conclusion}

Developing adequate assimilation strategies applied to anglicisms constitutes an important problem in cross-cultural and translation studies. The avalanche-like growth in the number of the borrowings from English in German calls for clarification and systematization. It should be noted that active borrowing per se isn't a strange thing, for language is a living organism, it preserves all the codes of the past and renews itself every generation, so there is no need to dramatize a mighty influx of anglicisms in German.

Two assimilation strategies have been identified in the text under analysis: the foreignising strategy, represented by code-mixing and partially integrated borrowings, and the neutralizing strategy, represented by double nomination and hybrid compounds. The neutralizing strategy outweighs quantitatively the foreignising one and indicates the overall trend towards a balanced approach to the incorporation of anglicisms (mixture of borrowed and native elements).

When we consider the borrowing process, we should bear in mind that professionally oriented texts are catering for the needs of specialists in a particular subject area, and consequently assimilation strategies applied to anglicisms should be consistent with the purposes and objectives of professional communication. Achieving high communication efficiency is considered one of the fundamental goals of the business discourse, therefore well-established high-frequency anglicisms should be incorporated by means of the foreignising strategy, whereas low-frequency anglicisms should be first introduced in the text by means of the neutralizing strategy, thus improving text coherence and ensuring optimal transmission of ideas. 


\section{References}

1. S.G. Ter-Minasova, Procedia - Social and Behavioral Sciences 154, 8-13 (2014). doi.org/10.1016/j.sbspro.2014.10.104

2. Isabel Kick, Die Wirkung von Anglizismen in der Werbung: „Just do it“ oder lieber doch nicht? (Diplomica Verlag GmbH, Hamburg, 2014).

3. Sabine Fiedler, Journal of Pragmatics 113, 89-102 (2017). doi.org/10.1016/j.pragma.2017.03.002

4. L.A. Nefedova, O.G. Polyakov, Procedia - Social and Behavioral Sciences 200, 83-86 (2015). https://doi.org/10.1016/j.sbspro.2015.08.020

5. Alexander Onysko, Esme Winter-Froemel, Journal of Pragmatics 43, 1550-1567 (2011). doi.org/10.1016/j.pragma.2010.12.004

6. Esme Winter-Froemel, Alexander Onysko, Andreea Calude, Language Contact in Times of Globalization, 119-142 (Peter Lang, Frankfurt am Main, 2014)

$\begin{array}{llllll}\text { 7. Sarah Josefine Schaefer, Lingua 221, 72-88 } & \text { (2019). }\end{array}$ doi.org/10.1016/j.lingua.2019.01.002

8. Matt Garley, Discourse, Context Media 3, 27-36 (2014). doi.org/10.1016/j.dcm.2013.11.001

9. Anna V. Zhiganova, Procedia - Social and Behavioral Sciences 236, 225-229 (2016) doi.org/10.1016/j.sbspro.2016.12.011

10. Leena Louhiala-Salminen, Anne Kankaanranta, Public Relations Review 38, 262-269 (2012). doi.org/10.1016/j.pubrev.2011.12.021.

11. W. Travis Selmier, Chang Hoon Oh, Business Horizons, 55, 189-200, (2012). doi.org/10.1016/j.bushor.2011.11.006

12. Csilla Weninger, Katy Hoi-Yi Kan, English for Specific Purposes 32, 59-71 (2013). doi.org/10.1016/j.esp.2012.09.002.

13. Anne-Wil Harzing, Kathrin Köster, Ulrike Magner, Journal of World Business 46, (2011). doi.org/10.1016/j.jwb.2010.07.005.

14. Crina Herteg, Teodora Popescu, Procedia - Social and Behavioral Sciences 93, 10801084 (2013). doi.org/10.1016/j.sbspro.2013.09.334

15. M.Yu. Semenova, Current Issues of Linguistics and Didactics: The Interdisciplinary Approach in Humanities and Social Sciences 50, (2018). https://doi.org/10.1051/shsconf/20185001156 